\title{
THE DIALECTICAL MATERIALISM OF PAULO FREIRE'S CRITICAL PEDAGOGY
}

Wayne $\mathrm{Au}^{1}$

\begin{abstract}
It is hard to over-emphasize Freire's importance to progressive, social justice, radical, and critical educators in the U.S. and around the world. The popularization of Freire and his conception of critical pedagogy has resulted in Freire's work being recontextualized in a variety of settings. However, despite important books on Freire's Marxist politics, his Marxist conception of consciousness, and the power of his legacy for teachers and activists, the popularity of Freire amongst "respectable" progressive educators has meant that the Marxist nature of his pedagogy is often left unsaid. This paper argues that, at its core, Freire's conception of critical pedagogy is based on Marxist, dialectical materialism. Further, this paper defends Freire's critical pedagogy from several detractors, most of whom maintain deep misunderstandings of Freire's dialectical materialism — and therefore propagate deeply misplaced criticisms of his pedagogy.
\end{abstract}

\section{Resumo}

É difícil enfatizar a importância de Freire para educadores radicais, progressistas, críticos e que lutam por justiça social nos EUA e em todo o mundo. A popularização de Freire e sua concepção de pedagogia crítica resultaram na recontextualização do trabalho de Freire em uma variedade de cenários. No entanto, apesar de importantes livros sobre a política marxista de Freire, sua concepção marxista de consciência, e o poder de seu legado para professores e ativistas, a popularidade de Freire entre educadores progressistas "respeitáveis" fez com que a natureza marxista de sua pedagogia fosse muitas vezes não dita. Este artigo argumenta que, em sua

\footnotetext{
${ }^{1}$ Wayne Au, Ph.D., Associate professor in the University of Washington Bothel, School of Educational; research focus in Educational equity, High-stakes testing, Curriculum theory, Educational policy studies and Social studies education. E-mail: wayneau@u.washington.edu.

Revista Reflexão e Ação, Santa Cruz do Sul, v. 25, n. 2, p. 171-195, Maio./Ago. 2017. http://online.unisc.br/seer/index.php/reflex/index
} 
essência, a concepção de Freire de pedagogia crítica se baseia no materialismo marxista e dialético. Além disso, este trabalho defende a pedagogia crítica de Freire de vários detratores, a maioria dos quais mantém profundos mal-entendidos do materialismo dialético de Freire - e, portanto, propagam críticas profundamente equivocadas de sua pedagogia.

\section{INTRODUCTION}

In many ways, the publication and distribution of Pedagogy of the Oppressed was a defining moment in the development of critical education. To be clear, there certainly were antecedents to Freire's critical pedagogy that just weren't named as such (APPLE; AU, 2015; LUKE, 2012), including the Harlem Socialist Sunday schools (MAKALANI, 2016; NAISON, 1985).or the critical pedagogies enacted in socialist, communist, and other countries pre-Freire (CHU, 1980; MCLAREN; SUORANTA, 2009). Also, even though he has often been mythologized as a "founding father" of critical pedagogy in the United States, Freire's work was not really popularized here until the mid-1980s, when the shift towards critical politics in education research and practice was already well under way (GOTTESMAN, 2010). All of that said, it is hard to over-emphasize Freire's importance to progressive, social justice, radical, and critical educators (GADOTTI; TORRES, 2009). The cover of the $30^{\text {th }}$ Anniversary Edition of Pedagogy of the Oppressed, published in the year 2000, boasted then that the book had sold over 1,000,000 copies worldwide (FREIRE, 2000). Use of Freire's work has become its own subfield within education, with numerous books, chapters, articles, and organizations being built around his name and ideals (APPLE, 1999; SCHUGURENSKY, 1998). In the process Freire and his conception of critical pedagogy have become commodified and recontextualized in ways great and terrible (AU; APPLE, 2006, 2007; GIBSON, 2006; SHOR; FREIRE, 1987; SHOR, 1987). Further, despite important books on Freire's Marxist politics (MACLAREN, 2000), his Marxist conception of consciousness (ALLMAN, 1999), and the power of his legacy for teachers and activists (DARDER, 2002), the popularity of Freire amongst "respectable" progressive educators has meant that the Marxist nature of his pedagogy is often left unsaid, unacknowledged, and or only spoken in hushed terms - as if we have to forgive him this trespass.

In this paper I want to push in two directions with regards to Freire. Mainly I want to argue

that, at its core, Freire's conception of critical pedagogy is based on a Marxist, dialectical 
materialism (AU; APPLE, 2007). In this way I want to firmly establish that Freire's pedagogy is Marxist, and in doing so help those who use and promote Freire's pedagogy understand the Marxist nature of that same pedagogy ${ }^{2}$. The secondary direction I push on here is to defend Freire's critical pedagogy from several detractors, most of whom maintain deep misunderstandings of Freire's dialectical materialism - and therefore propagate deeply misplaced criticisms of his pedagogy.

\section{DIALECTICAL MATERIALISM AND FREIRE'S EPISTEMOLOGY}

Before getting to the Marxist, dialectical materialism at the core of Freire's pedagogy, let me offer another quick review of dialectical materialism as a paradigmatic world view. A Marxist, dialectical view understands that all "things" are in fact processes-in-constant-motion and development, where the movement and development is driven by the tension created by two interrelated opposites acting in contradiction with each other and which, as a unified whole, require each other to exist. Further, in dialectics the world is seen as a multi-layered, interrelated system, a totality, a chain of relationships and processes (ALLMAN, 1999; GADOTTI, 1996; OLLMAN, 2003; SAYERS, 1990). It is critical to recognize that dialectical philosophy is qualitatively distinct from, if not oppositional to, the individualist rational logic of Western Enlightenment, most notably the positivistic sciences, which presumes that things exist in isolation of each other and are analyzed as if they fixed in space and time (BENTON; CRAIB, 2001). Conversely, in a dialectical world view everything is a process that can only be understood relationally other things/processes, all of which is moving and dynamic, and therefore cannot be analyzed as stagnant and motionless, independently existing pieces (ALLMAN, 1999).

Further, to be "materialist" in terms of dialectical materialism means that the material world exists outside of our consciousness of it. Following both Vygotsky (COLE; SCRIBNER, 1978) and Engels (1940), then, in a materialist view our consciousness comes from and is a reflection of our interaction with a material world that exists objectively outside of our subjective perceptions instead of the world emerging from human consciousness alone (AU, 1972). Dialectical thinking

\footnotetext{
${ }^{2}$ I'm making a distinction between Freire's critical/liberatory pedagogy and Freire the person. As Gibson, "Paulo Freire and Revolutionary Pedagogy for Social Justice", notes, Freire was Marxian in many areas, but he was also deeply religious in others. I would argue that Freire's pedagogy is perhaps more Marxist, dialectial mateiralist than Freire the person.
} 
and materialism are united within Marxist theory because the point is to (1) understand the interrelated processes happening in the material world and (2) to enable human intervention in those processes to change material conditions for the better. Within Freire's conception of critical pedagogy dialectical materialism provides a framework for analyzing objectively existing conditions in the world (i.e., various forms of institutionalized and systemic oppression), for understanding that humans can become actively conscious of both the conditions themselves and their sources, and for changing these conditions through human (social) intervention and action.

There is significant evidence that Freire was a materialist in terms of how humans understand and interact with the reality of our world, expressing in multiple places that the world existed objectively outside of human consciousness. He often framed this in terms of an “objective social reality” (FREIRE, 1974), “objective conditions” FREIRE, 2004) and general references to human interaction and transformation of "reality" or the "world" (FREIRE, 1974, 1992; FREIRE; MACEDO, 1987; SHOR; FREIRE, 1987). Freire also explicitly critiqued nonmaterialist perspectives on reality while affirming his position that an objective reality does indeed exist, when he states that:

Subjectivity starts by denying all concrete, objective reality and declares that the consciousness is the exclusive creator of its own concrete reality... Idealism errs in affirming ideas which are separate from reality govern the historical process. (FREIRE, 1973, p. 146-147)

This is not to assert that Freire believed that we know the objectively existing world in a completely objective manner. Rather, he posited a dialectical relationship between the objectively existing world and our subjective understanding of that world. For instance, Freire addresses the issue as follows:

Consciousness and the world cannot be understood separately, in a dichotomized fashion, but rather must be seen in their contradictory relations. Not even consciousness is an arbitrary producer of the world or of objectivity, nor is it a pure reflection of the world. (FREIRE, 1998, p. 19).

Despite his materialism, some have asserted that Freire did not believe that, "reality can be directly understood 'in itself"' (MORROW; TORRES, 2002, p. 34), essentially aligning him with what Lenin and others (BHASKAR, 1989) have correctly argued is ultimately a non-materialist conception of reality - because if you can't know material reality "in itself," then the existence of Revista Reflexão e Ação, Santa Cruz do Sul, v. 25, n. 2, p. 171-195, Maio./Ago. 2017. http://online.unisc.br/seer/index.php/reflex/index 
that reality is left completely to the subjective consciousness to create reality's existence. Rather, Freire saw the world as, "an objective reality, independent of oneself, capable of being known" (FREIRE, 1973, p. 3). Freire also regularly refers to the "knowable object" (FREIRE, 1973, p. 101, 149, 152, 161; SHOR; FREIRE, 1987, p. 100). Freire (1998, p. 66) perhaps most clearly expresses this view when he asserts that, "Our capacity to learn, the source of our capacity to teach, suggests and implies that we also have a capacity to grasp the substantiveness/essence of the object of our knowledge". Based on my reading of his work, I would argue that Freire did in fact see an objectively existing world outside of our consciousness (one that could be known and understood), but that he also recognized that we come to understand it through our subjective lenses as socio-cultural human beings (ROBERTS, 2003).

All of this philosophical argument is important because Freire's conception of human consciousness is a direct extension of his materialism (ROBERTS, 2003). Freire suggests that we are conscious because we, "are not only in the world, but with the world" (FREIRE, 1973 p. 3) and thus have "the capacity to adapt...to reality plus the critical capacity to make choices and transform that reality"(FREIRE, 1973, p. 4). This it can be consistently found from Freire's earlier work through his last writings (FREIRE, 1973; 1974), and it remains firmly within a Marxist, dialectical materialist conception of human consciousness (GILBERT, 2003; MARX; ENGELS, 1978). As Allman (1999, p. 37) explains:

Ideas and concepts arise from the relations between people and from relations between people and their material world (the world created by human beings as well as the natural world)...[where] we actively and sensuously experience these relations; therefore, our consciousness is actively produced within our experience of our social, material and natural existence.

Further, this relationship between consciousness and our material environments must also be thought of dialectically -as an interconnected interchange between humans and their social, cultural, and material environments, a relationships characterized by interaction, relational unity, and dynamic fluidity. This dialectical materialist conception provides the foundation for Freire's own formulation of consciousness, or conscientização, where he explains that:

Only when we understand the 'dialecticity' between consciousness and the world - that is, when we know that we don't have a consciousness here and the world there but, on the contrary, when both of them, the objectivity and the subjectivity, are incarnating 
dialectically, is it possible to understand what conscientização is, and to understand the role of consciousness in the liberation of humanity. (DAVIS; FREIRE, 1981, p. 62).

As such, and echoing both Vygotsky's (1987) and Lenin's (1975) conceptions of consciousness, Freire sees "consciousness as consciousness of consciousness" (FREIRE, 1974, p. 107), and that, "Consciousness is intentionality towards the world" (DAVIS; FREIRE, 1981, p. $58)$.

Further, and once again echoing Vygotsky (1966), Freire's conception of consciousness acknowledges that, because humans are part of the world, and because our consciousness arises from a dialectical interaction with that world (other humans included), our consciousness is first and foremost a social consciousness (FREIRE; MACEDO, 1987, 1995; ROBERTS, 2003). For Freire, as people, we therefore "...cannot think alone" and there "is no longer an 'I think' but 'we think"” (FREIRE, 1973, p. 137). Further, within Freire's conception, critical reflection creates the potential capacity to change the material world and our relations because we are not totally "determined beings" and we can "reflect critically about [our] conditioning process and go beyond it" (FREIRE, 1998, p. 20). Freire discusses the reciprocal, spiraling, dialectical relationship between reflection, action, and transformation as follows:

Human beings... are being of 'praxis': of action and of reflection. Humans find themselves marked by the results of their own actions in their relations with the world, and through the action on it. By acting they transform; by transforming they create a reality which conditions their manner of acting. (FREIRE, 1973, p. 102).

This process of critically reflecting on the world and taking conscious, purposeful transformative action defines Freire's conception of "praxis" (DAVIS; FREIRE, 1981; FREIRE, 1973, 1974).

Freire's critical pedagogy is also built upon a dialectical materialist presumption that we can know things as integrated totalities (ROBERTS, 2003) - using the language of Vygotsky, in more systematic and "scientific" ways. Freire explains that:

What we do when we try to establish a cognitive or epistemological relationship with the object to be known, when we get it into our hands, grasp it, and begin to ask ourselves about it, what we really begin to do is to take it as a totality. We then begin to split it into its constituent parts...In a certain moment, even though we may not have exhausted the process of splitting the object, we try to understand it now in its totality. We try to retotalize the totality which we split! The moment of summarizing has to do with this 
effort of retotalizing of the totality we divided into parts. (SHOR; FREIRE, 1987, p. $161)$.

For Freire, learning and developing critical consciousness happens through a dialectical process of breaking things down into related parts and then "retotalizing" them yet again to arrive at more complex, systematic understandings (FREIRE, 1974; FREIRE; MACEDO, 1995; FREIRE; SHOR, 1987).

In essence, the summary of Freire's Marxist, dialectical materialism that I have outlined here is also a summation of Freire's humanism. For Freire, to be human is to be able to both understand the world and take action to change that world: We are humanized through praxis (GLASS, 2001; ROBERTS, 2003). Freire's pedagogy extends directly from these same dialectical materialist underpinnings.

\section{FREIRE'S CRITICAL, LIBERATORY PEDAGOGY}

We need praxis or, in other words, we need to transform the reality in which we find ourselves. - Paulo Freire ${ }^{3}$.

Freire's formulation of critical, liberatory pedagogy is built with three goals in mind: First it must be a pedagogy that enables both teachers and students to develop more critically conscious, systematic understandings of their relationship with the world. For instance, he asserts that:

Education for freedom implies constantly, permanently, the exercise of consciousness turning in on itself in order to discover itself in the relationships with the world, trying to explain the reasons which can make clear the concrete situation people have in the world. (FREIRE; DAVIS, 1981, p. 59).

Second, and interrelated the first, is that this pedagogy, in developing critical consciousness, must be aimed at students and teachers becoming Subjects in education, people who, "become consciously aware of [their] context and [their] condition as a human being as Subject...[and] become an instrument of choice" (FREIRE, 1973, p. 56). In this way teachers and

\footnotetext{
${ }^{3}$ DAVIS; FREIRE, 1981, p. 59.

Revista Reflexão e Ação, Santa Cruz do Sul, v. 25, n. 2, p. 171-195, Maio./Ago. 2017. http://online.unisc.br/seer/index.php/reflex/index
} 
students are positioned as cognitive subjects and as, "critical agents in the act of knowing" (SHOR; FREIRE, 1987, p. 33). For Freire this means that,

All educational practice requires the existence of 'subjects,' who while teaching, learn. And who in learning also teach. The reciprocal learning between teachers and students is what gives educational practice its gnostic character. (FREIRE, 1998, p. 67).

The third goal of Freire's pedagogy is transformation, because it is not enough to merely reflect on the world in a critical manner as part of the development of consciousness, nor is it enough to establish the teacher's and student's rights to be a cognitive Subject in the process of learning. As Freire explains:

\begin{abstract}
Any attempt at mass education...must possess a basic aim: to make it possible for human beings, through the problematizing of the unity being-world (or of human beings in their relations with the world and with other human beings) to penetrate more deeply the prise de conscience of the reality in which they exist. This deepening of the prise de conscience, which must develop in the action which transforms reality, produces with this action an overlaying of basically sensuous knowledge of reality with that which touches the raison d'etre of this reality. People take over the position they have in their here and now. This results (and at the same time it produces this) in their discovering their own presence within a totality, within a structure, and not as 'imprisoned' or 'stuck to' the structure or its parts. (FREIRE, 1973, p. 107).
\end{abstract}

Hence, Freire's critical, liberatory pedagogy revolves around praxis and aims for students and teachers to be Subjects who can critically reflect upon that reality and take transformative action to change that reality - based on the original critical reflection. To do this, Freire suggests a pedagogical process of problem posing, coding/decoding, and dialogue as ways to develop critical consciousness to transformation both the classroom and the world.

\title{
3.1 Problem posing and decoding
}

In Pedagogy of the Oppressed Freire offers a clear summary of why problem-posing education works as a form of liberatory pedagogy:

In problem-posing education, [humans] develop their power to perceive critically the way they exist in the world with which and in which they find themselves; they come to see the world not as a static reality, but as a reality in process, in transformation. Although the dialectical relations of [humans] with the world exist independently of how these relations are perceived (or whether or not they are perceived at all), it is also true 
that the form of action [humans] adopt is to a large extent a function of how they perceive themselves in the world. (FREIRE, 1974, p. 70-71).

Problem-posing, then, is based on the idea that both material reality and our knowledge of that reality are not static or fixed - a core concept of dialectical materialism. This is fundamental to praxis, because if reality were fixed and unchanging, then we could do nothing to alter it, with or without our critical reflection - our lives would be completely determined, and we would no longer be Subjects of our own existences. Hence, Freire grounds problem-posing in action itself:

The process of problematization implies a critical return to action. It starts from action and returns to it. The process of problematization is basically someone's reflection on a content which results from an act, or reflection on the act itself in order to act better together with others within the framework of reality. There can be no problematization without reality. Discussion about transcendence must take its point of departure from discussion on the here, which for humans is always a now too. (FREIRE, 1973, p. 154).

Pedagogically the process of coding and decoding reality is at the root of problem posing: “The interlocutor-Subjects, faced with a pedagogical 'codification' (problemsituation)...concentrate on it, seeking through dialogue the significant comprehension of its meaning" (FREIRE, 1973, p. 161). This corresponds with the way that Freire explains that we develop consciousness through breaking reality down and retotalizing it through analysis and critical reflection. With problem-posing, a "problem-situation" is presented to or raised by the students. In this moment the "problem-situation" represents a perceived totality, and in the next movement the teacher and students move through a process of decoding the "problem-situation" - breaking it down, critically analyzing, picking it apart. The decoded "problem-situation" is then reconstructed through making more systemic, relational connections - making new sense of the problem within a new relational context.

There are many good examples of this process to be found in the pages of Rethinking Schools (www.rethinkingschools.org) and elsewhere. In my own teaching, one example would be the critical teaching of the concept of "race" in the U.S. My students generally come to me with uncritical, very commonsense understandings of race - they come to me with a conception of race that exists as a totality for them. I then problematize their existing understandings (their commonsense totalities) by decoding racial categories, pointing to the inconsistencies in using phenotype and genotype in the development of those categories, as well as dissecting the ways that racial language we use to name different races has changed and developed. At this point I've Revista Reflexão e Ação, Santa Cruz do Sul, v. 25, n. 2, p. 171-195, Maio./Ago. 2017. http://online.unisc.br/seer/index.php/reflex/index 
facilitated a process where my students' previous totality of racial understanding has been deconstructed. In a Vygotskian sense I have initiated the development of my students' spontaneous racial concepts towards more scientific racial concepts. In my instruction I then work to move my students towards more contextual and systemic understandings of race. This includes placing the U.S. racial categories in social, historical, and economic contexts, so that my students understand race relationally, with the ultimate goal of them developing more metaunderstandings of themselves and their own racial understandings.

Freire also discusses the process of coding/decoding in terms of the development and analysis of what he calls "generative themes." These themes are generated from the real life experiences of students, generated from "significant dimensions of an individual's contextual reality" (FREIRE, 1974, p. 94). Akin to the process of coding/decoding, these "significant dimensions" are analyzed as interacting pieces of "total reality," or what Freire also refers to as the "thematic universe." By critically analyzing these generative themes as part of a larger thematic universe (the totality), students and teachers can be introduced "to a critical form of thinking about their world" (FREIRE, 1974, p. 95). Perhaps most central to Freire's critical pedagogy is that problem posing and coding/decoding happen through a process of dialogue.

\subsection{Dialogue}

It would be difficult over-emphasize importance of dialogue in Freire's conception critical, liberatory pedagogy, which he sees as a general part of the development of human consciousness historically. He writes,

Dialogue must be understood as something taking part in the very historical nature of human beings. It is part of our historical progress in becoming human beings. That is, dialogue is a kind of necessary posture to the extent that humans have become more and more critically communicative beings. Dialogue is a moment where humans meet to reflect on the reality as they make and remake it. (SHOR; FREIRE, 1987, p. 98).

As human beings we know what we know (and what we don't know) through dialogue testament to the social nature of language itself (VIGOTSKY, 1987). Further, it is through reflection of this imperfect knowledge, that we can then improve our understanding and increase our capacities to transform reality (SHOR; FREIRE, 1987). Additionally, the act of dialogue 
automatically requires active reflection in relation to other human beings (as we "read" each other, think, ask questions, respond, etc.), grounding it both in the material world (society and culture included) and necessitating critical thinking. According to Freire, this is a type of critical thinking which,

[...] discerns an indivisible solidarity between the world and [humans] and admits of no dichotomy between them - thinking which perceives reality as process, as transformation, rather than as a static entity-thinking which does not separate itself from action...(FREIRE, 1974, p. 80-81).

Freire's dialectics are readily apparent here, as he explains that this critical thinking is never ending because reality itself is always undergoing movement and constant transformation. As such, humans are constantly taking part in this process and moving to action through dialogue with each other and in their interactions with the world.

In Freire's critical liberatory pedagogy, in dialogue about an object of study, "we try to reveal it, unveil it, see its reasons for being like it is, the political and historical context of the material. This...is the act of knowing..." (SHOR; FREIRE, 1987, p. 13). This in turn becomes the pedagogical foundation of dialogue, as Freire explains:

Since dialogue is the encounter in which the united reflection and action of the dialoguers are addressed to the world which is to be transformed and humanized, this dialogue cannot be reduced to the act of one person's 'depositing' ideas in another, nor can it become a simple exchange of ideas to be 'consumed' by the discussants... Because dialogue is an encounter among [humans] who name the world, it must not be a situation where some [humans] name it on behalf of others. (FREIRE, 1974, p. 77).

Hence, if we are in dialogue, we cannot "deposit" our ideas into other people - a form of teaching Freire famously and aptly called the "banking" method of education (FREIRE, 1974). Dialogue requires the social act of naming the world together in a process which also helps you understand it for yourself. Consequently, Freire posits that, "I cannot think for others or without others, no one can think for me...Producing and acting upon [our] own ideas-not consuming those of others-must constitute [this] process" (FREIRE, 1974, p. 100). Thus, students and teachers both exist in a dialogical relationship as Subjects where both learn from each other (FREIRE, 1998), where "the flow is in both directions" (FREIRE, 1973, p. 125).

\subsection{Freirian authority}

Revista Reflexão e Ação, Santa Cruz do Sul, v. 25, n. 2, p. 171-195, Maio./Ago. 2017. http://online.unisc.br/seer/index.php/reflex/index 
Importantly, in this relationship, even if the teacher may "know" more or differently about an object of study, the teacher also comes to re-know the object through the process of the student knowing the object as well (SHOR; FREIRE, 1987). As Freire explains, teachers and students are in thus remade:

Through dialogue, the teacher-of-the-students and the students-of-the-teacher cease to exist and a new term emerges: teacher-student with students-teachers. The teacher is no longer merely the one-who-teaches, but one who is [themselves] taught in dialogue with the students, who in turn while being taught also teach. They become jointly responsible for a process in which all grow. (FREIRE, 1974, p. 67).

However, being remade as "teacher-student with students-teachers" does not automatically establish a non-hierarchical relationship of total equality between teachers and students. Both still maintain their individual identities as dialectical opposites in the process of education. As Freire explains:

Dialogue between teachers and students does not place them on the same footing professionally...Teachers and students are not identical...After all, it is a difference between them that makes them precisely students or teachers. Were they simply identical, each could be the other. Dialogue is meaningful precisely because the dialogical subjects, the agents in the dialogue, not only retain their identity, but actively defend it, and thus grow together. Precisely on this account, dialogue does not level them, does not "even them out," reduce them to each other. (FREIRE, 1992, p. 101).

For Freire, the liberatory teacher is, "Not directive of the students," Rather, they are "directive of the process" (SHOR; FREIRE, 1987, p. 46). As such the liberatory teacher knows both the starting point for the learning process (knowledge of the object of study) and the, "the horizon that she or he wants to get to" (SHOR; FREIRE, 1987, p. 103), in that process. This means that while teachers may be an authority on the process of learning, or perhaps even an authority on a particular subject, they should not be authoritarian in that position. Freire explains, "[T]he moment the educator's 'directivity' interferes with the creative, formulative, investigative capacity of the educands, then the necessary directivity is transformed into manipulation, into authoritarianism" (FREIRE, 1992, p. 66). To be authoritarian would mean treating students as objects, essentially dehumanizing them. Liberatory pedagogy instead requires teachers to negotiate the relationship between freedom and authority in their classroom, and understand that, 
"authority... has its foundation in the freedom of others" (SHOR; FREIRE, 1987, p. 91). Such a position requires that the teacher is neither completely hands off ("laissez faire") nor authoritarian and dictatorial. Rather, liberatory educators are "radically democratic" in their pedagogy, which includes being "responsible and directive" while also respecting students' fundamental rights to come to their own conclusions (FREIRE; MACEDO, 1995).

\subsection{A Pedagogy of social transformation}

Finally, it is critical to recognize that Freire's liberatory pedagogy is enacted in the material, already existing world. Because of this, like everything else, Freire's pedagogy is inherently ideological, political, and not neutral. Similarly, liberatory pedagogy cannot be disentangled from a broader project of social change because its goal of developing critical consciousness is operationalized through students, teachers, and knowledge itself, all of which are dialectically interrelated with the world. If the point of liberatory pedagogy is to be praxis, to embody critical reflection in action, then conscious knowledge of the world cannot be decoupled from taking action in the world as well. Liberatory pedagogy is not a pedagogy contained the classroom alone, because it is inextricably linked to social action as well (FREIRE, 1974; SHOR; FREIRE, 1987). In an excellent discussion in A Pedagogy for Liberation (SHOR; FREIRE, 1987) and perhaps echoing Bowles and Gintis (1976), Freire is clear that, while schools are not powerful enough to be a totalizing driving force for social transformation, because of the key role that they play in the development of critical consciousness in the world, they are absolutely essential in building mass movements.

\subsection{Critics of Freire's critical pedagogy}

Thus far I have demonstrated how Freire's conception of critical, liberatory pedagogy flows directly from Marxist, dialectical materialism. My intent has been to show how grasping Freire's Marxism allows for a deeper understanding of Freire's pedagogy (ALLMAN, 1999). The importance of this connection between Freire's pedagogy and Marxist, dialectical materialism cannot be overstated, because Freire's pedagogy does not make sense without it. This is a crucial point because, as one of the most influential educational thinkers of the $20^{\text {th }}$ century, Freire's 
books, words, and ideas have traveled the world, moved through time, and have been used in a wide variety of contexts outside of Brazil. Such widespread exposure has inevitably - and rightfully - pushed the limits of Freire's critical, liberatory pedagogy, which has led to several scholarly and conceptual critiques. The natures of these critiques have differed dramatically. Some have arisen out of a serious engagement with Freire's political project and growing social and pedagogical movements, while others have been built upon overly-simplistic reads of Freire's politics and pedagogy.

One such example of an overly-simplistic read of Freire's politics and pedagogy can be found in the collection, Rethinking Freire (BOWERS; APFFEL-MARGLIN, 2005). In it, under the leadership of Chet Bowers (a constant critic of Freire), several indigenous scholars launched a series of critiques of Freirian pedagogy aimed at completely undermining its validity. These critiques include assertions that Freire and his pedagogy are fundamentally individualist and based in Enlightenment philosophy (BOWERS, 2005; RASMUSSEN, 2005; ROBINSON, 2005; VASQUEZ, 2005), philosophically committed to a linear development of culture RASMUSSEN; SIDDHARTHA, 2005), conceives of teacher student relations in an elitist manner (BEJARANO, 2005; ESTEVA; STUCHUL; PRAKASH, 2005; RASMUSSEN, 2005), disregards the role schools play in social reproduction and maintaining oppression (ESTEVA; STUCHUL; PRAKASH, 2005), colonizes indigenous cultures (VAZQUEZ, 2005), devalues indigenous knowledge (RASMUSSEN, 2005), and disregards environmentalism and is anthropocentric (BOWERS, 2005; RASMUSSEN; SIDDHARTHA, 2005).

If we look at the depth and breadth of Freire's work, as I have done here in this paper, it is clear these critiques are largely misplaced and based on a very limited, perhaps mistaken, reading of Freire and the dialectical materialist basis for his pedagogy (APPLE; AU, 2007). For instance, take the claims that Freire's pedagogy promotes individualism (BOWERS, 2005; RASMUSSEN, 2005; ROBINSON, 2005; VASQUEZ, 2005). This assertion about Freire's work is not new (ELLSWORTH, 1998; WEILER, 1995), and it is based on an understanding of Freire as the ideological descendant of the Western rationalism associated with the European Enlightenment. By extension, these critics would argue, Freire's critical, liberatory pedagogy is colonizing to indigeneity, imperialistic, and dismissive of environmental issues. This critique misses Marxist, dialectical materialism in Freire's pedagogy altogether. As I have explained at length previously in this paper, Freire's conception of consciousness and transformation is entirely social, not 
individual. He was very clear in his pedagogy and analysis that he saw no dichotomy between humans and the world around them - other humans included (FREIRE, 1973, 1974; FREIRE; MACEDO, 1995). As I highlighted earlier, Freire conceptions of consciousness is built upon the idea that there is an ongoing, dialectical, and reflexive relationship between individuals and the world - a social consciousness - such that there is no "I think" and only a "we think" (FREIRE, 1973, p. 137). Further, such a conception is also the basis for seeing strong, dialectical connections between humans and their environments (ENGELS, 1940; COLE; SCRIBNER, 1978), a point that speaks to environmental and ecological strengths of Freire's pedagogy as well (GRUENEVALD, 2003). To suggest that Freire's pedagogy inherently promotes individualism as part of the lineage of Western rationality simply does not grasp Freire's dialectical, materialist conception of human consciousness as being fundamentally based in human collectivity in interaction with our environments.

Rethinking Freire (Bowers \& Apffel-Marglin, 2005) offers other examples of how a failure to grasp Freire's dialectical materialism leads to other kinds of misreadings and misapplication of Freire's liberatory pedagogy. For instance, several of these critics suggest that Freire's conception is fundamentally elitist, does not recognize or honor indigenous knowledge, and is based on an authoritarian relationship between teachers and students (BEJARANO, 2005; ESTEVA; STUCHUL; PRAKASH, 2005; RASMUSSEN; SIDDHARTHA, 2005). This critique misses the ways that Freire both recognizes that teachers do maintain a specific type of democratic authority in the classroom and that students and teacher are jointly responsible for leadership within the pedagogic relationship, something Freire consistently emphasizes across his writings (FREIRE, 1973, 1994, 1992). As I argued above, Freire's Marxist, dialectical materialism essentially sees humans - both teachers and students - as being in constant interaction and in constant development, while also recognizing that individuals can only think for themselves as part of consciousness that arises socially. Further, Freire's dialectical, materialist conception of pedagogy does not allow for the teacher to be elitist or to disregard student/indigenous knowledge and perspective (MACLAREN, 2000) because, for Freire, developing critical consciousness is based on, and begins with, the input, experience, participation, and perspectives of students themselves. As Freire explains:

With progressive education, respect for the knowledge of living experience is inserted into the larger horizon against which it is generated... Respect for popular knowledge, Revista Reflexão e Ação, Santa Cruz do Sul, v. 25, n. 2, p. 171-195, Maio./Ago. 2017. http://online.unisc.br/seer/index.php/reflex/index 
then, necessarily implies respect for cultural context. Educands' concrete localization is the point of departure for the knowledge they create in the world. "Their" world, in the last analysis, is the primary and inescapable face of the world itself. (FREIRE, 1992, p. 72).

To claim that Freire's conception of critical, liberatory pedagogy is based on the assumption that teachers are an elite vanguard that deliver the "correct" knowledge to the people is to claim that Freire advocates a "banking" form of education - a form which we know lies in direct opposition to Freire's pedagogy (APPLE; AU, 2007).

Freire himself cognizant of how partial understandings of his philosophy and pedagogy had led some to view his work negatively. In reflecting on this issue he remarked that:

One of the reasons that many progressive and liberal educators in the United States have difficulty in comprehending [my] concept...is not necessarily because they are incapable of understanding the concept. It is perhaps because they have only absorbed the substance of my ideas to a certain degree, while remaining ideologically chained to a position that is anti-Freirian. Thus, by only partially accepting my ideological aspirations, they then develop doubts and questions with respect to specific methods and techniques. In this way they rationalize their total movement away from critically embracing what I represent in terms of theoretical proposals for change and for radical democracy and for history as possibility and for a less discriminatory society and a more humane world. (FREIRE, 1997, p. 328).

It would appear that by not grasping the dialectical materialism of Freire's pedagogy, the contributors to Rethinking Freire have rationalized "their total movement away" from Freire, thereby positioning themselves as anti-Freirian via claims that Freire's pedagogy as inherently oppressive (APPLE; AU, 2007).

Another important example of an educator absorbing "the substance of [Freire's] ideas to a certain degree, while remaining ideologically chained to a position that is anti-Freirean" (FREIRE, 1997, p. 328) can be found in the work of Elizabeth Ellsworth, who sparked an academic controversy (LETTERS) when she wrote about how her attempt at using critical pedagogy failed and ultimately strengthened the structures of oppression and dominance in her university classroom. In the article Ellsworth recounts how her application of critical pedagogy, her version of Freirean pedagogy included was detrimental for her as a white women teaching students of color, and arrives at the conclusion that Freirean pedagogy upholds universal truths, is based in the rationality of Western logic, does not recognize subjectivity, does not recognize that knowledge is socially constructed, does not ask teachers to be critically reflexive of their own 
identities in relation to their students, upholds "repressive myths," and perpetuates "discourses of dominance" in the classroom (ELLSWORTH, 1989).

The critical piece here is that, in her article, Ellsworth declared that it was her position as a white woman that kept her from being able to understand the racism her students were facing. While I appreciate her recognition of her positionality relative to her students, in doing so Ellsworth functionally argues that we cannot understand the world outside of our subjective, individual experiences. Consequently, Ellsworth concluded that she could not develop any material knowledge or understanding of her students, their experiences, and their identities, which then caused her difficulties implementing an anti-racist, critical pedagogy in her university class. This aspect of Ellsworth's article and difficulties is critical because it illustrates how, fundamentally, her orientation towards consciousness about the world stands in deep ideological opposition to the dialectical materialism that is at the base of Freire's conception of critical, liberatory pedagogy - which strongly asserts that we can understand the world around us, including the experiences of others.

Ellsworth's fundamental difference with Freirean epistemology and pedagogy thus ended up subverting her classroom dynamics in several ways. Ultimately it kept Ellsworth from being authoritative (in the Freirean sense) in the classroom because, as she asserts, she could not help her students learn about racism since, as a white person, she cannot know or understand it. In response she chose to take a hands-off, lassez-faire approach to classroom relations, pedagogy, and content, because, from her own pedagogic perspective, she was then not in a position to direct the learning process. Hands-off, lassez-faire pedagogy has been found to actually increase existing inequalities (SHARP; GREEN, 1975), and is an approach that Freire himself has vehemently critiqued as reproducing oppression in the classroom (SHOR; FREIRE, 1987). Simply put, Ellsworth's failure to implement Freirean pedagogy arose because she was fundamentally "chained to a position that is anti-Freirean" (FREIRE, 1997, p. 328).

\section{RECLAIMING LIBERATORY PEDAGOGY FOR MARXIST, DIALECTICAL MATERIALISM}

The point here has not been to argue that Freire was somehow perfect in his conception of liberatory pedagogy. He was just as fallible and imperfect as any of us. However, part of my 
argument here has been that some critiques are more substantial and warranted than other. To that end, there are critiques of his work that are much more in solidarity of the political project of education for social justice and social transformation. For instance, Freire has been rightly critiqued for using discriminatory language, including the "universal man" and overly general terms such as "oppressor" and "oppressed" (WEILER, 1991) Freire has also been critiqued for not adequately addressing issues of race (HAYMES, 2002; LADSON-BILLINGS, 1997; LEONARDO et al., 2005), for not explicitly dealing with feminist and gender issues (WEILER, 1991), and for neglecting overlapping forms of oppression (GLASS, 2001; SCAPP, 1997; WEILER, 1991). Others have also pointed out that Freire assumed that critical consciousness automatically developed people in progressive ways (FINE, 1997).

Many critical scholars have also upheld critiques of Freire while explicitly aligning themselves with Freire and his work. Several feminist scholars have maintained an affinity between Freire and feminism (HOOKS, 1994; STEFANOS, 1997; WEILER, 1991), and critical race scholars in education used his work to build robust theoretical frameworks for understanding the relationship between liberatory pedagogy and racial justice (ALLEN, 2005; LEONARDO, 2005; SOLOZARNO; YOSSO, 2005). These represent instances of pushing on the boundaries and edges of Freire's liberatory pedagogy as well as a fruitful route towards the growth of critical pedagogy more generally. Regardless of their natures, these critiques of Freire's pedagogy point to a critical issue: The cultural, historical, political, and philosophical origins of Freire's work shape how his are read and how his conceptualization are understood. In this regard Freire's intent was to provide, "the possibility for the educator to use my discussions and theorizing about oppression and apply them to a specific context" (FREIRE, 1997, p. 309), which he felt could be applied to deal with racism and women's oppression in other contexts like the United States (FREIRE; MACEDO, 1995) and Guinea-Bissau (FREIRE; MACEDO, 1987).

Freire took up these more substantial critiques in his later books and essays. In Pedagogy of Hope (1992), Freire admits that as soon as Pedagogy of the Oppressed was published in 1970, he received letters from women around the world criticizing his use of the "universal man" in his writing. Freire explained that he had not meant to alienate women in his writing, and that the issue had not occurred to him when he used the term "man" to mean all of humanity. Freire immediately committed himself to changing his language from then on. In response to other criticisms regarding race and gender, Freire has reflected: 
When I wrote Pedagogy of the Oppressed, I tried to understand and analyze the phenomenon of oppression with respect to its social, existential, and individual tendencies. In doing so, I did not focus specifically on oppression marked by specificities such as color, gender, race, and so forth. I was more preoccupied then with the oppressed as a social class. But this, in my view, does not at all mean that I was ignoring the many forms of racial oppression that I have denounced always and struggled against even as a child...Throughout my life I have worked against all forms of racial oppression, which is in keeping with my desire and need to maintain coherence in my political posture. I could not write in defense of the oppressed while being a racist, just as I could not be a machista either. (FREIRE, 1997, p. 309).

Here Freire offers an incomplete defense, but he does at least how his overall paradigm of anti-oppression, in whatever forms oppression takes (race, class, gender, ability, sexuality, etc.) was central to his project. Further, he also highlights how he was interested in developing an overarching framework for understanding how education can contribute to liberation generally, even if he did not focus on the nuances of how, for instance, race or gender manifest in that process.

In general, these criticisms of Freire's critical, liberatory pedagogy should be welcomed. Indeed, as Freire himself noted:

Criticism creates the necessary intellectual discipline, asking questions to the reading, to the writing, to the book, to the text. We should not submit to the text or be submissive in front of the text. The thing is to fight with the text, even though loving it, no? (SHOR; FREIRE, 1987, p. 11).

His Marxist, dialectical materialist understanding of the development of consciousness, as well as the pedagogies he developed to move learners towards critical consciousness and action are all based on the fundament of critical self-reflection. Criticism, especially of the fightingloving kind that I would say is more akin to what it means to struggle over issues with friends, comrades, or family members, is central to the ongoing development of critical consciousness which itself is central to Freire's broader political project of revolutionary social change. And that is the important thing to keep in mind, and what has been neglected as Freire's name has been coopted by deregulated charter schools, neoliberal corporations, and even moved into the mainstream of progressive education: Freire's liberatory pedagogy is a part of the Marxist, dialectical materialist tradition, and as such, it is fundamentally anti-capitalist and has the goal of upending capitalist relations (MACLAREN, 2000). This is why Freire was jailed and exiled, why 
Freirian pedagogy is so powerful for teaching and organizing, and why right wing conservatives remain bitter and fearful about his influence in U.S. education (STER, 2009).

\section{REFERÊNCIAS}

ALLEN, Ricky Lee. Whiteness and critical pedagogy. In: LEONARDO, Zeus. Critical Pedagogy and race. Malden, MA: Blackwell Publishing, 2005. p. 53-68.

ALLMAN, Paula. Revolutionary social transformation: democratic hopes, political possibilities and critical education. 1st ed. Critical Studies in Education and Culture Series. Westport, CT: Bergin \& Garvey, 1999.

APPLE, Michael W. Power, meaning and identity: essays in critical educational studies, studies in the Postmodern Theories of Education. New York: Peter Lang, 1999.

. General introduction. In: APPLE, M. W.; AU, W. (ed.). Critical education. v. 1 e 4. New York: Routledge, 2015. p. 1-28.

APPLE, M. W.; AU, W. Introduction. In: APPLE, M. W.; AU, W. (ed.). Critical education. v. 1 e 4. New York: Routledge, 2015. p. 29-32.

Freire, critical education, and the environmental crisis. Educational Policy 21, n. 3, p. 457-70, jul. 2007.

. Reclaiming communist philosophy: Marx, Lenin, Mao, and the dialectics of nature, marxist, socialist, and communist studies in education. Charlotte, NC: Information Age Publishing, 2017.

AU, Wayne. Reclaiming communist philosophy: Marx, Lenin, Mao, and the dialectics of nature; V.I. Lenin, materialism and empirio-criticism. Peking: Foreign Language Press, 1972.

BEJARANO, Barbara Loyda Sanchez. Who are the oppressed? In: In: BOWERS, C. A.; APFFEL-MARGLIN, F. Rethinking Freire: globalization and the environmental crisis. Mahwah, New Jersey: Lawrence Erlbaum Associates, Publishers, 2005. p. 49-67.

BENTON, T.; CRAIB, I. Philosophy of social science: the philosophical foundations of social thought, traditions in social theory. New York: Palgrave, 2001.

BHASKAR, Roy. Reclaiming reality: a critical introduction to contemporary philosophy. 2nd KW. New York: Verso, 1989.

BOWERS, C. A. How the ideas of Paulo Freire contribute to the cultural roots of the ecological crisis. In: BOWERS, C. A.; APFFEL-MARGLIN, F. Rethinking Freire: globalization and the 
environmental crisis. Mahwah, New Jersey: Lawrence Erlbaum Associates, Publishers, 2005. p. 133-50.

BOWERS, C. A.; APFFEL-MARGLIN, F. Rethinking Freire: globalization and the environmental crisis. Mahwah, New Jersey: Lawrence Erlbaum Associates, Publishers, 2005.

BOWLES, S.; GINTIS, H. Schooling in capitalist America: educational reform and the contradictions of economic life, 1st ed. New York: Basic Books, 1976.

COLE, M.; SCRIBNER, S. Introduction. In: Mind in society: by L. S. Vygotsky. Cambridge, MA: Harvard University Press, 1978. p. 1-14.

CHU, Don-chean; Chairman Mao: education of the proletariat. New York: Philosophical Library, 1980.

DARDER, Antonia. Reinventing Paulo Freire. Boulder, Colorado: Westview Press, 2002.

DAVIS, R.; FREIRE, P. Education for awareness: a talk with Paulo Freire. In: MACKIE, Robert. Literacy and Revolution: the pedagogy of Paulo Freire. New York: The Continuum Publishing Company, 1981. p. 62.

ELLSWORTH, Elizabeth. Why doesn't this feel empowering?: Working through the repressive myths of critical pedagogy. Harvard Educational Review 59, n. 3, p. 297-324, 1989.

ENGELS, Frederick. Dialectics of nature. Translation by C. Dutt. 1st ed. New York: International Publishers, 1940.

ESTEVA, G.; STUCHUL, D. L.; PRAKASH, M. S. From a pedagogy of liberation to liberation from pedagogy. In: BOWERS, C. A.; APFFEL-MARGLIN, F. Rethinking Freire: globalization and the environmental crisis. Mahwah, New Jersey: Lawrence Erlbaum Associates, Publishers, 2005. p. 13-30.

FINE, Michelle. A letter to Paulo. In: FREIRE, P. et al. Mentoring the mentor: a critical dialogue with Paulo Freire. Studies in the Postmodern Theories of Education. New York: Peter Lang, 1997. p. 89-97.

FREIRE, P.; MACEDO, D. Literacy: reading the word and the world. Tranlation by Donaldo Macedo. Westport, Connecticut: Bergin \& Garvey, 1987.

377-402, 1995.

FREIRE, Paulo. Education for critical consciousness. New York: Bloomsbury Press, 1973. 2000.

Pedagogy of the oppressed. 30th Anniversary Edition. New York: Bloomsbury Press, 
Pedagogy of the oppressed, New York: Bloomsbury Press, 1974.

. Pedagogy of freedom: ethics, democracy, and civic courage. Tranlation by Patrick

Clarke, 2001st ed. New York: Rowman and Littlefield Publishers Inc., 1998.

. Pedagogy of indignation. Boulder, Colorado: Paradigm Publishers, 2004.

Pedagogy of hope: reliving pedagogy of the oppressed. Translation by Robert R. Barr.

2004th ed. New York: Continuum Publishing Company, 1992.

. Politics and education. Translation by Pia Lindquist Wong. Los Angeles: UCLA Latin

American Center Publications, 1998.

A response. In: FREIRE, P. et al. Mentoring the mentor: a critical dialogue with Paulo

Freire. Studies in the Postmodern Theories of Education. New York: Peter Lang, 1997. p. 328.

GADOTTI, Moacir. Pedagogy of praxis: a dialectical philosophy of education. Translation by J. Milton, 1st ed. Albany, NY: State University of New York Press, 1996.

GADOTTI, M.; TORRES, C. A., Paulo Freire: education for development. Development and Change 46, n. 2, p. 1255-67, 2009.

GIBSON, Rich. Paulo Freire and revolutionary pedagogy for social justice, In: ROSS, E.W.; GIBSON, R. (ed.). Neoliberalism and education reform. Cresskill, New Jersey: Hampton Press, Inc., 2006. p. 177-236.

GILBERT, Grant. Marx, wittgenstein an the problem of consciousness. In: PETERS, M. et al. Critical theory and the human condition: founders and praxis. Studies in the Post Modern Theory in Education. v. 168. New York: Peter Lang, 2003. p. 101-13.

GLASS, Ronald D. On Paulo Freire's philosophy of praxis and the foundations of liberation education. Educational Researcher 30, n. 2, p. 15-25, 2001.

GOTTESMAN, Isaac. Sitting in the waiting room: Paulo Freire and the critical turn in the field of education. Educational Studies 46, n. 4, p. 376-99, 2010. doi:10.1080/00131941003782429.

GRUENEWALD, David A. The best of both worlds: a critical pedagogy of place. Educational Researcher 32, n. 4, p. 3-12, 2003.

HAYMES, Stephen Nathan. Race, pedagogy, and Paulo Freire. Philosophy of education yearbook, p. 151-59, 2002.

HOOKS, Bell. Teaching to transgress: education as the practice of freedom. New York: Routledge, 1994. 
LADSON-BILLINGS, Gloria. I know why this doesn't feel empowering: a critical race analysis of critical pedagogy. In: FREIRE, P. et al. Mentoring the mentor: a critical dialogue with Paulo Freire. Studies in the Postmodern Theories of Education. New York: Peter Lang, 1997. p. 12741.

LEONARDO, Zeus. Critical pedagogy and race. Malden, Massachussetts: Blackwell Publishing, 2005.

LENIN, I. What is to be done?: burning questions of our movement. Peking: Foreign Language Press, 1975.

LETTERS. Harvard educational review 60, no. 3; 1990; p. 388-405.

LUKE, Allan. Critical Literacy: Foundational Notes. Theory Into Practice 51, n. 4, 2012. p. 4-11.

MAKALANI, Minkah. An apparatus for negro women: black women's organizing, communism, and the instutional spaces for radical pan-african thought. Women, Gender, and Families of Color 4, n. 2, p. 250-73, 2016.

MACLAREN, Peter. Che Guevara, Paulo Freire and the pedagogy of revolution. Lanham, Md.: Rowman \& Littlefield Publishers, 2000.

MARX, K.; ENGELS, F. The German Ideology: Part I. In: TUCKER, R. C. The Marx-Engels Reader. New York: W.W. Norton \& Company, 1978. p. 146-200.

MCLAREN, P.; SUORANTA, J. Socialist Pedagogy. In: HILL, Dave. Contesting neoliberal education. London: Routledge, 2009. p. 242-64.

MORROW, R. A.; TORRES, C. A. Reading Freire and Habermas: critical pedagogy and transformative social change. New York: Teachers College Press, 2002.

NAISON, Mark. Communists in Harlem during the depression. New York: Grove Press Inc., 1985.

RASMUSSEN, Derek. Cease to do evil, then learn to do good... (a Pedagogy for the oppressor). In: BOWERS, C. A.; APFFEL-MARGLIN. Rethinking Freire: globalization and the environmental crisis. Mahwah, New Jersey: Lawrence Erlbaum Associates, Publishers, 2005. p. 115-31;

RASMUSSEN, D.; SIDDHARTHA. Cease to do evil, then learn to do good... (a Pedagogy for the oppressor); From conscientization to interbeing: a personal journey. In: BOWERS, C. A.; APFFEL-MARGLIN. Rethinking Freire: globalization and the environmental crisis. Mahwah, New Jersey: Lawrence Erlbaum Associates, Publishers, 2005. p. 83-100. 
ROBERTS, Peter. Knowledge, dialogue, and humanization: exploring Freire's philosophy. In: PETERS, M. et al. Critical theory and the human condition: founders and praxis. Studies in the Post Modern Theory in Education v. 168. New York: Peter Lang, 2003. p. 169-83.

ROBINSON, Phyllis. Whose oppression is this?: The Cultivation of Action in Dissolving the Dualistic Barrier. In: BOWERS, C. A.; APFFEL-MARGLIN. Rethinking Freire: globalization and the environmental crisis. Mahwah, New Jersey: Lawrence Erlbaum Associates, Publishers, 2005. p. 101-14;

OLLMAN, Bertell. Dance of the dialectic: steps in Marx's Method, 1st ed. Chicago: University of Illinois Press, 2003.

SAYERS, Sean. Marxism and the dialectical method: a critique of G.A. Cohen. In: SAYERS, S.; OSBORNE, P. (ed.). Socialism, feminism, and philosophy: a radical philosophy reader. New York: Routledge, 1990. p. 140-68.

SCAPP, Ron. The subject of education: Paulo Freire, postmodernism, and multiculturalism. In: FREIRE, P. et al. Mentoring the mentor: a critical dialogue with Paulo Freire. Studies in the Postmodern Theories of Education. New York: Peter Lang, 1997. p. 283-91.

SHARP, R.; GREEN, A. Education and social contro: a study in progressive primary education. London: Routledge \& Kegan Paul, 1975.

SHOR, I.; FREIRE, P. A pedagogy for liberation: dialogues on transforming education. South Hadley, Mass.: Bergin \& Garvey Publishers, 1987.

SHOR, Ira. Freire for the classroom: a sourcebook for liberatory teaching. Portsmouth, New Hampshire: Boynton/Cook Publishers, Heinemann, 1987.

SCHUGURENSKY, Daniel. The Legacy of Paulo Freire: a critical review of his contributions, Convergence 31, n. 1/2., p. 17-29, 1998.

SOLOZARNO, D.; YOSSO, T. Maintaining social justice hopes within academic realities: a freirean approach to critical rac/latcrit pedagogy. In: LEONARDO, Zeus. Critical pedagogy and race. Malden, MA: Blackwell Publishing, 2005. p. 69-92.

STEFANOS, Asgedet. African women and revolutionary change: a freirian and feminist perspective. In: FREIRE, P. et al. Mentoring the mentor: a critical dialogue with Paulo Freire. Studies in the Postmodern Theories of Education. New York: Peter Lang, 1997. p. 243-71.

STERN, Sol.Pedagogy of the oppressor: another reason why U.S. ed Schools are so awful: the ongoing influence of Brazilian Marxist Paulo Freire. City Journal, 2009. Disponível em: <https://www.city-journal.org/html/pedagogy-oppressor-13168.html>. 
VASQUEZ, Grimaldo Rengifo. Nurturance in the Andes. In: BOWERS, C. A.; APFFELMARGLIN. Rethinking Freire: globalization and the environmental crisis. Mahwah, New Jersey: Lawrence Erlbaum Associates, Publishers, 2005. p. 31-47;

VIGOTSKY, Lev S. Thinking and speech. In: RIEBER, R. W.; CARTON, A. Translation by Norris Minick The collected works of L.S. Vygotsky: problems of general psychology including the volume thinking and speech. v. 1. New York: Plenum Press, 1987. p. 37-285.

VIGOTSKY, Lev S. Development of Higher Mental Functions. In: LEONTYEV, A.; LURYIA, A. Psychological research in the U.S.S.R., Smirnov, Moscow: Progress Publishers, 1966. p. 1145

WEILER, Kathleen. Freire and a feminist pedagogy of difference. Harvard Educational Review 61, n. 4, p. 449-74, 1991. 